\title{
Effect of Porpoise Oil on Kidney of Rats Receiving High Fat Diet
}

\author{
Nema A. Soliman, Walaa A. Keshk \\ Medical Biochemistry Department, \\ Faculty of Medicine, Tanta University, Egypt
}

\begin{abstract}
Background Obesity is the number one preventable risk factor for chronic kidney disease. Multiple observational studies have documented an association between obesity and risk of kidney disease even after adjustment for obesity-related co-morbid conditions, including diabetes mellitus. Because diet specially dietary fat has been recognized as contributing to the development and prevention of obesity, the influence of quantities and qualities of dietary fat on the pathogenesis of obesity related renal disorders has been studied. It has been known that tissues of porpoise contain unique structured-lipids as combination of iso-valeric acid (iso-C5:0) and $\omega-3$ polyunsaturated fatty acids ( $\omega-3$ PUFA). It is well known that $\omega-3$ PUFAs have lipidlowering effects in animal and human studies. Omega3-polyunsaturated fatty acids can prevent or alleviate obesity-related disorders through the suppression of fatty acid synthesis, enhancement of fatty acid $\beta$-oxidation. In the present study the effect of structural-lipids from porpoise adipose tissue (porpoise oil) on lipid metabolism was investigated. Design In this study 4 groups of male albino rats (n=10/group): group 1 received control diet $10.6 \%$ fat, group 2 received high fat diet (HFD) $53.15 \%$ fat, group 3 received HFD 53.15\% fat with porpoise oil from start of induction of obesity and group 4 received HFD 53.15\% fat and followed by addition of porpoise oil for 4 weeks after induction of obesity. All groups were subjected to the assay of serum levels of total lipid profile, urea, creatinine, fasting glucose and insulin as well as the levels of free fatty acid (FFA), malondialdehyde (MDA) and nitric oxide (NO). Also, renal tissue levels of triacylglycerol (TAG), FFA, and MDA and NO as well as aldose reductase (AR) activity were assayed, with estimation of urinary albumin level. Results: There was statistically significant improvement in all parameters of renal function, oxidative stress and dyslipidemia under the effect of porpoise oil intake. Conclusions: The current results might lead us to better utilization of porpoise oil due to its content of $\omega-3$ PUFA to reduce lipid deposition in the kidney tissue with improving its functions, therefore presenting an opportunity for developing new strategies to treat obesity.

Key words: obesity, high fat diet (HFD), porpoise oil, free fatty acid (FFA), malondialdehyde (MDA), nitric oxide (NO), triacylglycerol (TAG), aldose reductase (AR), omega-3 poly unsaturated fatty acids (n-3 PUFA)
\end{abstract}




\section{INTRODUCTION}

Obesity is a condition of
abnormal or excessive fat
accumulation to the extent that
increase the risk of suffering from
type II diabetes mellitus,
cardiovascular disease, cancer and
renal diseases. Obesity is considered
as a result of long-term energy
imbalance and it has been linked to
increased dietary intake, especially
saturated fat, and sedentary lifestyle ${ }^{(1)}$.
Obesity in animal model is usually
taken as any significant increase in
body weight or energy content relative
to control animals. The induction of
obesity may be performed in animals
by neuroendocrine, dietary or genetic
changes ${ }^{(2)}$.

Oxidative stress is loss of the equilibrium between the generation of oxidants and antioxidant systems. Oxidative stress is an important mediator of damage to cell structures including cell membrane, lipids, nucleic acids and proteins. The major aldehyde product of lipid peroxidation is malondialdehyde (MDA) ${ }^{(3)}$.

In the kidney, a number of pathways generate reactive oxygen species (ROS) such as high intracellular glucose level, polyol pathway activation, inducible nitric oxide synthase (iNOS) and lipotoxicity contribute to localized tissue oxidative stress $^{(4)}$. Aldose reductase (AR), a key enzyme in the polyol pathway, catalyzes reduction of glucose to sorbitol whose intracellular accumulation might cause renal tubular reabsorption dysfunction ${ }^{(5)}$.

Quality and quantity of dietary fat had different effects on the pathogenesis of obesity and its complications. Modification of fatty acid composition and/or their location in the glycerol backbone can improve the physical and/or physiological properties of dietary lipids, in particular, $\omega-3$ polyunsaturated fatty acids $(\omega-3 \text { PUFA })^{(6)}$. Omega-3 poly unsaturated fatty acids from fish oil eicosapentaenoic acid (EPA) and docosahexaenoic acid (DHA) are more biologically potent than those from plants. Fish oil $\omega-3$ PUFA affect eicosanoid metabolism and cytokine production ${ }^{(7)}$. Porpoise oil contains structural lipids as combination of isovaleric acid (iso-C5) and $\omega-3$ PUFA $^{(\mathbf{8})}$.

Therefore, our aim was to develop obesity in rat by high fat diet (HFD) and to estimate the biochemical changes and mechanisms that link obesity with altered renal function to shed light on the effect of obesity on kidney and its improvement with porpoise oil to give a new hope for controlling the effect of obesity on the kidney functions.

\section{MATERIAL \& METHODS}

The current work was carried out in accordance with the guidelines of the Ethical Committee of Medical Research of Faculty of Medicine Tanta University. All chemicals were obtained from Sigma Chemical Company, Bio-diagnostic Dokki, Giza, Egypt, Diamond Diagnostic, Egypt, Spinreact, Egypt and Sigma Scientific Service, Egypt. All the remaining chemicals were of the highest analytical grade. All the solutions used for enzyme assays were 
prepared using deionized water to eliminate trace metal contaminations.

The present study was carried out on 40 white male albino rats their weight ranged 110-116 grams. During the study, the animals were kept in wire mesh cages with ad libitum access to water. The room temperature was about $22-24^{\circ} \mathrm{C}$ and the animals were exposed to $12: 12$ hours light dark cycles. The animals were randomly divided into four equal groups. All animals were given one week to acclimate to lab conditions, during that time they were maintained on ad libitum (laboratory chow and water).

Group I (control group): Ten rats given control diet (low fat diet), $10.6 \%$ fat, $59.7 \%$ carbohydrate and $27.3 \%$ protein during the entire study (12 weeks). Composition of the control diet ( $\mathrm{g} / \mathrm{kg}$ diet) was according to the formula of Dourmashkin et al. ${ }^{(9)}$.

Group II (obese group): Ten rats given HFD, $53.15 \%$ fat, $27.17 \%$ carbohydrate and $19.68 \%$ protein during the entire study (12 weeks). Composition of the HFD ( $\mathrm{g} / \mathrm{kg}$ diet) was according to the formula of Dourmashkin et al. ${ }^{\left({ }^{(9)}\right.}$.

Control diet and HFD constituents were purchased from El-Gomhoria Company, Cairo, Egypt. High fat diet was preserved at $4^{\circ} \mathrm{C}$ until used. Obesity was induced in 12 weeks.

Group III: Ten rats received HFD for 12 weeks with porpoise oil intake from the start with a dose of I $\mathrm{ml} / \mathrm{kg}$ /day by oral administration through nasogastric tube.

Group IV: Ten rats received the high fat diet for 12 weeks followed by porpoise oil intake with a dose of I $\mathrm{ml} / \mathrm{kg} /$ day by oral administration through nasogastric tube for another 4 weeks with HFD.

Sampling and tissue preparation:

By the end of the experimental period, all fasting rats (8-12 hours) were sacrificed and blood and tissue samples were collected.

\section{Blood sampling:}

Sera were separated and stored in aliquots at $-70^{\circ} \mathrm{C}$ till used for estimation of fasting plasma glucose by oxidase method using assay kit (Biodiagnostic, Egypt), serum urea and creatinine by colorimetric methods using commercial kits (Diamond Diagnostic, Egypt), total lipid profile including total cholesterol (TC), triglycerides (TG) and highdensity lipoprotein cholesterol (HDL) by colorimetric methods using assay kits (Biodiagnostic, Egypt). Lowdensity lipoprotein cholesterol (LDL) concentration was calculated according to Friedewald et al.(1972) ${ }^{\mathbf{1 0}}$. Insulin level was measured by Enzyme-Linked Immunosorbent Assay (ELISA) technique and calculation of homeostasis model assessment for insulin resistance $(\text { HOMA-IR })^{(11)}$. Free fatty acid $(\mathrm{FFA})^{(12)}, \mathrm{MDA}^{(13)}$ and nitric oxide $(\mathrm{NO})^{(14)}$ levels were measured according to Falholt et al. (1973), Ohkawa (1979) and Miranda et al. (2001) respectively.

Urine sampling:

Random urine samples were obtained for assay of urinary albumin according to the method of Wrenn et al. ${ }^{(15)}$ using commercial kits (Biodiagnostic, Egypt). .

Tissue sampling:

At the end of the experiment, rats were sacrificed by decapitation and 
the abdomen was opened, kidneys and visceral adipose tissue were removed. Kidney was taken, cleared of the adhering fat, weighed, washed by ice cold saline, dried by filter paper and the lipids were extracted according to Folch et al. ${ }^{(\mathbf{1 6})}$. Kidney was spliced into 3 pieces and stored at $-70^{\circ} \mathrm{C}$, then underwent homogenization with a potter- Elvenhjem tissue homogenizer (30 up and down strokes) in phosphate buffer saline (PBS) $50 \mathrm{mM} \mathrm{pH} \mathrm{(7.4)}$ for estimation of protein content according to the colorimetric methods of Lowry et al. ${ }^{(17)}$ as well as TG, FFA levels according to the methods reported previously, potassium phosphate buffer $10 \mathrm{mM} \mathrm{pH}$ (7.4) for estimation of MDA and NO levels according to the methods reported previously and $5 \mathrm{mM}$ PBS $\mathrm{pH}$ (6.2) containing $10 \mathrm{mM}$ mercaptoethanol for estimation of AR activity according to Song et al. ${ }^{(\mathbf{1 8})}$. The crude tissue homogenate was centrifuged at $10,000 \mathrm{rpm}$, for 15 minutes in cold centrifuge, and the resultant supernatant was used for the previous different estimations.

Statistical analysis:

All the statistical analyses were processed using Statistical Program of Social Sciences (SPSS) for windows, version 10.0. Values of the measured parameters were expressed as mean value $\pm \mathrm{SD}$ and the difference between the four groups was determined using ANOVA test, and the significance was considered at $\mathrm{p}$ values $<0.05$.

\section{RESULTS}

Figure (1) shows a comparison of body weight (BW) gain of rats in grams throughout the experimental study each separated by 2 weeks interval among all studied groups using ANOVA-test. There was significant difference between them (p-value <0.05) with significantly higher increase in the body weights of the group receiving HFD alone more than control group. Administration of porpoise oil minimizes the increase in body weight.

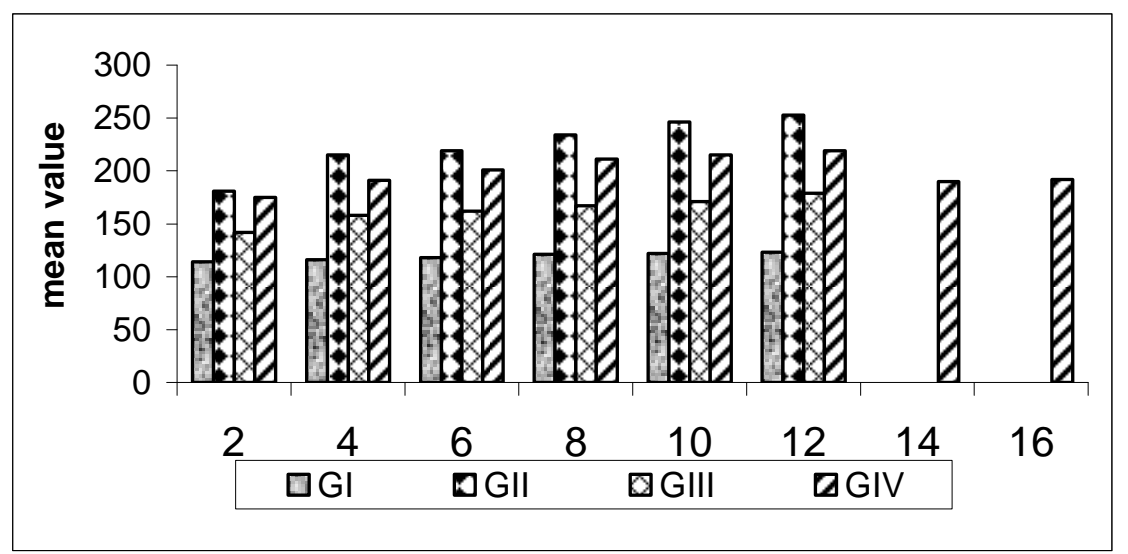

Figure (1) Comparison of BW gain in grams of rats throughout the experimental study separated by 2 weeks interval among all studied groups. 
Table (1) shows that body, kidney and visceral adipose tissue weights increased significantly in rats on the HFD alone compared with body weight of control group, while treatments with porpoise oil significantly reduced this gain during the treatment period with porpoise oil.

Table (1): Comparison between all studied groups as regard body, kidney and visceral adipose tissue weights

\begin{tabular}{|l|l|l|l|l|l|l|}
\hline & $\begin{array}{l}\text { GI } \\
(\mathbf{n}=\mathbf{1 0})\end{array}$ & $\begin{array}{l}\text { GII } \\
(\mathbf{n = 1 0})\end{array}$ & $\begin{array}{l}\text { GIII } \\
(\mathbf{n = 1 0})\end{array}$ & $\begin{array}{l}\text { GIV } \\
(\mathbf{n}=\mathbf{1 0})\end{array}$ & $\begin{array}{l}\text { F. } \\
\text { test }\end{array}$ & $\begin{array}{l}\text { p. } \\
\text { value }\end{array}$ \\
\hline Body weight (g.) & $124.3+8.6$ & $261.4+20.5$ & $178.2 \pm 11.3$ & $213.7 \pm 14.9$ & 6.362 & $0.008^{*}$ \\
\hline Kidney weight (g.) & $0.6 \underline{+0.04}$ & $2.11 \pm 0.32$ & $1.24 \pm \underline{0.19}$ & $1.85 \pm 0.34$ & 2.410 & $0.033^{*}$ \\
\hline Visceral adipose tissue (g.) & $3.21 \pm 0.74$ & $19.3 \pm 7.5$ & $12.3 \pm 2.7$ & $17.4 \underline{+8.6}$ & 3.626 & $0.013^{*}$ \\
\hline
\end{tabular}

* Significant at P-value $<0.05$

Table (2) shows significant increase in urinary albumin level, serum levels of urea, creatinine, TAG, total cholesterol (TC), low density lipoprotein-cholesterol (LDL-C) with low level of high density lipoprotein-cholesterol (HDL-C) in rats on the HFD alone compared with control group. While, administration of porpoise oil significantly improved these changes with more improvement occurs in the group received porpoise oil from the start of induction of obesity.

Table (2): Statistical comparison between all studied groups as regards lipid profile, renal function tests and urinary albumin level

\begin{tabular}{|c|c|c|c|c|c|c|}
\hline & GI $(n=10)$ & $\begin{array}{l}\text { GII } \\
(n=10)\end{array}$ & $\begin{array}{l}\text { GIII } \\
(n=10)\end{array}$ & $\begin{array}{l}\text { GIV } \\
(n=10)\end{array}$ & F. test & p. value \\
\hline $\begin{array}{l}\text { Urinary Albumin } \\
\text { level (mg/24 hours) }\end{array}$ & $10.63 \pm 0.63$ & $33.88 \pm 0.96$ & $15.79 \pm 0.68$ & $21.63 \pm 1.29$ & 6.362 & $0.001 *$ \\
\hline Urea level (mg/dl) & $20.3+1.4$ & $38.1+0.85$ & $22.36+2.43$ & $22.4 \pm 1.7$ & 3.620 & $0.007 *$ \\
\hline Creatinine, (mg/dl) & $0.4 \pm 0.06$ & $0.82 \pm 0.17$ & $0.51 \pm 0.08$ & $0.52 \pm 0.10$ & 4.712 & $0.014^{*}$ \\
\hline TAG level (mg/dl) & $86.3+2.7$ & $330.4 \pm 10.8$ & $216.1 \pm 7.5$ & $263.7 \pm 3.7$ & 7.623 & $0.001 *$ \\
\hline TC level (mg/dl) & $79.5+3.2$ & $311.4+13.2$ & $167.8+9.6$ & $260.1+5.7$ & 4.421 & $0.010^{*}$ \\
\hline LDL level-C (mg/dl) & $25.3 \pm 1.9$ & $233.1 \pm 8.6$ & $91.4 \pm 5.3$ & $182.4 \pm 4.7$ & 5.302 & $0.019^{*}$ \\
\hline HDL-C level (mg/dl) & $36.1+2.9$ & $23.4+\overline{5} .3$ & $32.2+2.7$ & $26.4 \pm 2.8$ & 4.622 & $0.048^{*}$ \\
\hline
\end{tabular}

* Significant at P-value $<0.05$

Table (3) shows that serum levels of glucose, insulin, MDA and FFA were significantly raised as well as the calculated HOMA-IR, while NO levels were significantly lowered in rats on the HFD alone compared with control group. These alterations were ameliorated by administration of porpoise oil with more improvement occurs in the group received porpoise oil from the start of induction of obesity. 
Table (3): Statistical comparison between all the studied groups as regard serum levels of MDA, FFA, NO, fasting glucose and fasting insulin as well as the calculated of HOMA-IR.

\begin{tabular}{|c|c|c|c|c|c|c|}
\hline & GI $(n=10)$ & GII $(n=10)$ & $\begin{array}{l}\text { GIII } \\
(n=10)\end{array}$ & GIV $(n=10)$ & F. test & $\begin{array}{l}\text { p. } \\
\text { value }\end{array}$ \\
\hline $\begin{array}{ll}\text { Fasting } \\
(\mathrm{mg} / \mathrm{dl})\end{array}$ & $86.5 \pm 7.2$ & $139.5 \pm 6.8$ & $111.2 \pm 3.3$ & $123.4 \pm 6.2$ & 5.326 & $0.008 *$ \\
\hline $\begin{array}{l}\text { Fasting insulin level } \\
(\mu \mathrm{IU} / \mathrm{ml})\end{array}$ & $5.10+0.86$ & $33.5 \pm 4.2$ & $12.1+1.2$ & $22.3 \pm 2.6$ & 3.963 & $0.019 *$ \\
\hline HOMA.IR & $1.06 \pm 0.11$ & $11.3+1.5$ & $3.28+0.93$ & $6.68 \pm 1.47$ & 3.654 & $0.013 *$ \\
\hline MDA (nmol/ml) & $2.71 \pm 0.63$ & $4.92 \pm 0.67$ & $3.68+0.91$ & $3.96 \pm 0.47$ & 2.152 & $0.047 *$ \\
\hline FFA level & $22.10+0.59$ & $41.26+1.22$ & $25.74+0.12$ & $31.26+1.14$ & 2.963 & $0.028 *$ \\
\hline NO level $(\mu \mathrm{mol} / \mathrm{l})$ & $2.84 \pm 0.32$ & $1.91 \pm 0.24$ & $2.10 \pm 0.30$ & $1.82 \pm 0.09$ & 4.996 & $0.027 *$ \\
\hline
\end{tabular}

* Significant at $\mathbf{P}$-value $<0.05$

Table (4) shows that tissue levels of TG, FFA and MDA as well as AR activity were significantly raised, while tissue NO level was significantly lowered in rats on the HFD alone compared with control group. These alterations were ameliorated by administration of porpoise oil with more improvement occurs in the group received porpoise oil from the start of induction of obesity.

Table (4): Statistical comparison between all studied groups as regards to kidney tissue TAG,FFA, NO,MDA level and AR enzyme activity

\begin{tabular}{|c|c|c|c|c|c|c|}
\hline & $\begin{array}{l}\text { GI } \\
(n=10)\end{array}$ & $\begin{array}{l}\text { GII } \\
(n=10)\end{array}$ & $\begin{array}{l}\text { GIII } \\
(n=10)\end{array}$ & $\begin{array}{l}\text { GIV } \\
(n=10)\end{array}$ & $\begin{array}{l}\text { F. } \\
\text { test }\end{array}$ & $\begin{array}{l}\text { p. } \\
\text { value }\end{array}$ \\
\hline TG level (mg/g. tissue) & $5.99+0.37$ & $12.10+0.58$ & $8.51+0.63$ & $10.73+0.29$ & 1.336 & 0.147 \\
\hline FFA level (mg/g. tissue) & $6.11+0.99$ & $12.10 \pm 0.42$ & $8.56 \pm 0.37$ & $10.63 \pm 0.47$ & 5.632 & 0.005 \\
\hline NO level ( $\mu \mathrm{mol} / \mathrm{g}$. tissue) & $1.43+0.38$ & $0.76+0.09$ & $0.91+0.20$ & $0.81+0.08$ & 6.326 & 0.001 \\
\hline MDA level (nmol/g. tissue) & $1.24 \pm 0.25$ & $6.75 \pm 1.47$ & $3.58 \pm 0.62$ & $3.01 \pm 0.42$ & 3.226 & 0.017 \\
\hline $\begin{array}{l}\text { AR activity (umol NADPH/ } \\
\min ^{-1} / \mathrm{g}^{-1} \text { protein) }\end{array}$ & $0.61 \pm 0.07$ & $1.52 \pm 0.21$ & $0.76 \pm 0.11$ & $0.70 \pm 0.10$ & 3.556 & 0.042 \\
\hline
\end{tabular}

* Significant at P-value $<0.05$

\section{DISCUSSION}

Obesity is a complex metabolic disorder characterized by an excess of body fat and represent one of the major public health problems, dietary factors, particularly the consumption of HFD is considered a risk factor for its development ${ }^{(\mathbf{1 9})}$.

Hypercaloric diet is the simplest obesity-induction model, and closely resembles the reality of obesity in humans. Rat model is a useful tool for inducing experimental obesity as they will readily gain weight when fed 
HFD containing more saturated fat, and due to great similarity between the genomes of rodents and humans ${ }^{(20)}$.

Obesity is an important independent risk factor for kidney disease because of renal intracellular lipid accumulation, obesity associated hypertension, hyperglycemia, dyslipidemia and oxidative stress ${ }^{(21)}$.

In the present study, a HFD containing $53.15 \%$ of its calories from fat as vegetable oil was used to induce obesity in albino rats. Obesity was induced within 12 weeks. The body, kidney and visceral adipose tissue weights gained by rats on HFD formula, was significantly more than that gained by those on control diet $(10.6 \%$ of its calories is derived from fat). This may be due to HFD-induced hyperphagia and the high energy value of HFD ${ }^{(22)}$, such result is in accordance with that of Akiyama et al. ${ }^{\text {(23) }}$. Visceral and renal fat accumulation through consumption of HFD may contribute to increased intra-renal pressure and physically compress the kidneys ${ }^{(24)}$.

Our results showed a significant decrease in whole body, kidney and visceral adipose tissue weights from oral administration of porpoise oil especially in the group fed porpoise oil from the start of obesity induction (group 3) than those fed porpoise oil for 4 weeks after obesity induction (group 4). Mathai et al. ${ }^{(25)}$ reported that $\omega-3$ PUFA supply may control the food intake, especially in conditions of reduced glucose availability in the cells as in diabetes mellitus. Different forms of dietary fat were reported to change the expression of neuropeptide genes involved in energy homeostasis in different way ${ }^{(26)}$.

Influx of FFA in the proximal tubule normally occurs via reabsorptive endocytosis of filtered albumin. Increased filtration of FFAbearing albumin and/or an increased FFA/albumin ratio may contribute to proximal tubule FFA overload and renal lipotoxicity. Lipotoxicity is the accumulation of excess lipids in tissues other than adipose tissues. Lipotoxicity cause cellular dysfunction mainly due to direct toxic effects of FFA which cause loss of mitochondrial membrane potential with ATP depletion, activation of apoptosis, and peroxynitrite generation $^{(27)}$. Organ weight measurement is important to access general toxicity because any change in organ weight is a sensitive indicator of toxicity ${ }^{(28)}$.

This current study revealed that obese rats on HFD had significantly higher serum levels of TC, TG, LDL$\mathrm{C}$, serum and tissue FFA and renal tissue TG, and low level of HDL-C, compared to control group, a finding in accordance with that of Woo et al. $^{(29)}$ and Kochikuzhyil et al. ${ }^{(30)}$. This may be due to dietary lipid ingestion and insulin resistance which enhances the lipolytic activity of visceral adipocytes increasing FFA release and their supply to the liver resulting in increased VLDL synthesis and secretion ${ }^{31}$. Decreased HDL-C level may be due to increased HDL catabolism as a result of insulin resistance and increased FFAs levels which increased hepatic lipase activity to remove lipids from LDL and $\mathrm{H} \backslash \mathrm{DL}$ making them denser and smaller ${ }^{32}$. 
Porpoise oil supplementation produced significant decreases in serum levels of TC, TG, LDL-C, serum and tissue FFA and renal tissue TG, while there was significant increases in HDL-C in obese rats with more improvement in group fed porpoise oil from the start of obesity induction than group fed porpoise oil for 4 weeks after induction. From the current data, it could be suggested that porpoise oil has hypolipidemic action. This could be explained by suppression of hepatic lipogenesis, enhanced fatty acid oxidation in the liver and skeletal muscle as well as enhancing the flux of glucose to glycogen by $\omega-3$ PUFA content of porpoise oil ${ }^{(33)}$. These studies were extensively reviewed and reported $^{(34,35)}$.

The current study also revealed higher level of urinary albumin, fasting blood glucose, fasting plasma insulin and HOMA-IR in rats on HFD than the control ones, which parallels the results obtained by Lu et al. ${ }^{(36)}$ and Afonso et al. ${ }^{(37)}$ These results could be attributed to nutrient overload, inflammation, oxidative stress, deficiency of active insulin receptors causing hyperinsulinemia ${ }^{38}$. Hyperinsulinemia causes downregulation of the insulin receptors, later on exhaustion of the $\beta$ cell function and overt type II diabetes mellitus occurs. Increasess in insulin, FFA, and/or glucose levels cause more oxidative stress and more ionpairment of both insulin action and secretion $^{39}$.

Porpoise oil administration to HFD fed rats reduced significantly urinary albumin, blood glucose and plasma insulin level and HOMA-IR index, with more improvement in group fed porpoise oil from the start of induction than group fed porpoise for 4 weeks after induction. These results are in accordance with those obtained by Storlien et al. ${ }^{(40)}$. This effect may be due to improvement of insulin action by $\omega-3$ PUFA contents of porpoise oil, through suppression of hepatic lipogenesis, reducing the hepatic output of TG, inducing FA oxidation, decreasing inflammatory cytokines, reducing expression of iNOS, decreasing ROS production and improving glucose uptake and glycogen synthesis ${ }^{\mathbf{( 4 1 , 4 2 )}}$.

Lifestyle and diet play an important role in the development of kidney disease. The obese rats showed a highly significant increase in the concentration of serum urea and creatinine in HFD group compared with the control group, a finding which is in agreement with the result of Cindik et al. ${ }^{(40)}$. The oral administration of porpoise oil led highly significantly decrease in serum levels of urea and creatinine in group fed porpoise oil from the start of induction than group fed porpoise for 4 weeks after obesity induction. The effect of porpoise oil on renal lipid metabolism could serve as a new therapeutic approach, as it counters the renal changes associated with metabolic syndrome, and has beneficial effects on renal function.

Nitric oxide is synthesized continuously in the endothelium from L-arginine by endothelial nitric oxide synthase (eNOS). It plays an important role in maintaining basal vascular tone, inhibits platelet and leukocyte adhesion to vascular endothelium, and inhibits proliferation 
of smooth muscle cells through its effect on the soluble Guanylate Cyclase signaling pathway ${ }^{(44)}$. It plays an important role in the regulation of renal blood flow to the renal medulla and in the tubular regulation of sodium excretion. ${ }^{(45)}$. The current study revealed lower level of $\mathrm{NO}$ in serum and kidney tissue in rats on HFD than the control ones. This may be due to NO inactivation by ROS and decreased NO synthase activity. Nitric oxide deficiency may contribute to renal vascular congestion and the renal dysfunction $\operatorname{progression}^{(46)}$.

The oral administration of porpoise oil led to highly significantly increase in serum and kidney tissue NO levels in the group fed porpoise oil from the start of obesity induction than group fed porpoise for 4 weeks after obesity induction. This effect may be due to increased vascular synthesis of NO, decreased oxidative stress, improvement of dyslipidemia and hyperglycemia associated with administration of porpoise oil that results in replenish of NO level to normal ${ }^{(47)}$.

Aldose reductase catalyzes reduced nicotinamide adenine dinucleotide phosphate (NADPH) dependent reduction of glucose to sorbitol. This current study revealed higher level of renal tissue AR activity in rats on HFD than the control ones. This may be due to hyperglycemia and increased intracellular glucose level which activate polyol pathway that cause accumulation of sorbitol ${ }^{(48)}$. Sorbitol decreases the activity of $\mathrm{Na}^{+}$$\mathrm{K}^{+}$-ATPase as well as increased expression of cytokines and proteins including transforming growth factor
(TGF- $\beta$ ) and fibronectin which cause thickening of the glomerular basement membrane and renal tubular reabsorption defect ${ }^{48}$.

The oral administration of porpoise oil led to highly significant decrease in kidney tissue AR activity in the group fed porpoise oil from the start of obesity induction than group fed porpoise oil for 4 weeks after obesity induction this effect is due to decreased blood glucose level and the improvement in insulin sensitivity of the glomerular cells ${ }^{(49)}$.

Obesity per se may induce systemic oxidative stress through increased ROS production via obesity associated hyperglycemia, hyperinsulinemia, FFA, increased NADPH oxidase and decreased antioxidant enzymes. ROS generated in oxidative stress activate nuclear factor kappa-B (NF- KB) that triggers the transcription of several mediators of inflammation with more ROS genK eration ${ }^{(50)}$. This current study also revealed higher level of MDA in serum and kidney tissue from HFD rats than the control ones, indicating oxidative stress in the renal tissue which causes lipid peroxidation. Our results are in agreement with the results of Olusi et al. ${ }^{(51)}$ and Amirkhizi et al. ${ }^{(52)}$. The oral administration of porpoise oil showed that MDA in serum and kidney tissue were highly significantly decreased in group fed porpoise oil from the start of obesity induction than group fed porpoise oil for 4 weeks after obesity induction this can be explained by amelioration of oxidative stress state by porpoise oil administration.

From these data it could ve suggested that HFD might cause renal 
oxidative stress and renal lipotoxicity which are associated with lower renal NO, so HFD can initiate glomerular vasoconstriction and renal lipotoxicity favouring nephropathy.

\section{CONCLUSION}

Collectively, feeding HFD to rats resulted in significant elevation in body weight, visceral fat weight, blood levels of glucose, insulin, TAG, TC, LDL-C, serum and renal tissue MDA, serum and renal tissue FFA, renal tissue TAG and AR activity with significant decrease in serum and renal NO levels in our obesity model. All of these parameters implicated in renal disorders and produce adverse effects on kidney.

Administration of porpoise oil improved these changes as it improves blood glucose level, insulin sensitivity, dyslipidemia, lipid peroxidation which is cytotoxic by reducing free-radical production and by increasing NO production/availability. NO improves renal vascular tone so that kidney function is improved. Porpoise oil can protect the kidney from deleterious effect of bad feeding habit and obesity but further studies is required to explain whether these effects is due to $\omega-3$ PUFA component alone or other component of porpoise share these effects.

Our data offer novel insights into potential mechanisms of renal dysfunction in obesity and demonstrate the efficacy of porpoise oil in renal protection and weight management.

\section{REFERANCES}

1- Kramer H, Luke A (2007): Obesity and kidney disease: a big dilemma. Curr. Opin. Nephrol. Hypertens., 16(3): 237-241

2- York DA (1996): Lessons from animal models of obesity. Endocrinol. Metab. Clin. North Am., 25(4): 781-800

3- Bandyopadhyay U, Das D and Banerjee RK (1999). Reactive oxygen species: oxidative damage and pathogenesis. Current Science 77(5): 658-666

4- Abdelnaser B, Rizk E, Amr MA, Ahmed E, Nadeem AK, Ayman E and Alaa W (2011). Oxidative stress and not endothelial Nitric Oxide Synthase gene polymorphism involved in diabetic nephropathy. Journal of Diabetes and Endocrinology 2(3); 29-35

5- Wang Z, Jiang T, Li J, Proctor G, McManaman JL, Lucia S, Chua S, Levi M. (2005). Regulation of renal lipid metabolism, lipid accumulation, and glomerulo-sclerosis in FVBdb/db mice with type 2 Diabetes. Diabetes 54(8):232835.

6- De Caterina $R$, Madonna $R$, Bertolotto A, Schmidt EB. (2007): $\omega-3$ Fatty Acids in the Treatment of Diabetic Patients Biological rationale and clinical data Diabetes Care 30(4): 10121026

7- Karlström BE, Järvi AE, Byberg L, Berglund LG, Vessby BO. (2011): Fatty fish in the diet of patients with type 2 diabetes: comparison of the metabolic effects of foods rich in n-3 and $\omega-6$ fatty acids. Am. J.Clin.Nutr., 1(94); 26-33

8- Shirouchi B, Naga K, Furuya $K$, Nagai $T$, Ichioka $K$, Tokairin S, Lida $Y$ and 
Yanagita T (2010). Physiological functions of iso-type short- chain fatty acids and omega 3 polyunsaturated fatty acids containing oil in obese OLETF rats. J. Oleo Science 59(6); 299305

9- Dourmashkin JT, Chang GQ, Hill JO, Gayles EC, Fried SK and Leibowitz SF (2006). Model for predicting and phenotyping at normal weight the long-term propensity for obesity in Sprague-Dawley rats. Physiol. Behav., 87(4): 666-678

10- Friedewald WT, Levy RI, and Fredrickson DS (1972): Estimation of the concentration of low density lipoprotein cholesterol in plasma without use of the preparative ultracentrifuge. Clin. Chem., 18:499 - 502.

11- Duseja A, Thumburu KK, Das A, Dhiman RK, Chawla YK, Bhadada $S$ and Bhansali $A$ (2007): Insulin tolerance test is comparable to homeostasis model assessment for insulin resistance in patients with nonalcoholic fatty liver disease. Indian J. Gastroenterology 26(4): 170-173

12- Falholt K, Lund $B$ and Falholt W (1973): An easy colorimetric micromethod for routine determination of free fatty acids in plasma. Clin. Chim. Acta 46(2): 105-11.

13- Ohkawa H, Ohishi $N$ and Yagi K (1979): Assay for lipid peroxides in animal tissues by thiobarbituric acid reaction. Anal. Biochem., 95(2): 351358(2):

14- Miranda KM, Espey MG and Wink DA (2001): A rapid, simple spectrophotometric method for simultaneous detection of nitrate and nitrite. Nitric Oxide 5(1); 62-71

15- Wrenn HT and Feichtmeir TV (1956): The quantitation of albumin based on dye linear binding capacity. Am. J. Clin. Pathol., 26(8): 960-968

16- Folch J, Lees $M$ and Sloane Stanly GH (1973). A simple method for the isolation and purification of total lipids from animal tissues. J. Biol. Chem., 226(1):497-509

17- Lowry OH, Rosenbrough NJ, Farr AL and Randall RJ (1951): Protein measurements with the Folin phenol reagent. J. Biol. Chem., 193(1): 265-275

18- Song HP, Has B, Srivastava SK (1987): Micro-determination of aldose and aldehyde reductases from human tissues. Curr. Eye Res., 6(8): 1001-6.

19- Woods SC, Seeley RG, Rushing PA, D'Alessio D, and Tso $P$ (2003): A controlled high-fat diet induces an obese syndrome in rats. J. Nutr., 133(4):1081-7

20- Dourmashkin JT, Chang GQ, Hill JO, Gayles EC, Fried SK and Leibowitz SF (2006): Model for predicting and phenotyping at normal weight the long-term propensity for obesity in Sprague-Dawley rats. Physiol. Behav 9. 87(4): 666-678

21- Weinberg J M (2006): Lipotoxicity. Kidney International 70(9): 1560-1566

22- Sastre J, Pallardó FV, Llopis J, Furukawa T, Viña JR and Vina J (1989): Glutathione depletion by hyperphagia- induced-obesity. Life sci. 945(2); 183-187

23- Akiyama T, Tachibana I, Shirohara H, Watanabe $\mathbf{N}$ and Otsuki M (1996): High-fat hypercaloric diet induces obesity, glucose intolerance and hyperlipidemia in normal adult male Wister rat. Diabetes Res. Clin. Pract., 31(1-3); 27-35

24- Norazmir MN and Ayub MY (2010): Beneficial lipidlowering effects of pink guava puree in high fat diet induced- 
obese rats. Malays. J. Nutr., 16(1); 171-185

25- Mathai ML, Soueid M, Chen N, Jayasooriya AP, Sinclair AJ, Wlodek ME, Weisinger HS, Weisinger RS. (2004): Does perinatal $\omega-3$ polyunsaturated fatty acid deficiency increase appetite signaling?. Obes. Res.,12(11): 1886-1894

26- Dziedzic B, Szemraj J, Bartkowiak $J$ and Walczewska A (2007): Various dietary fats differentially change the gene expression of neuropeptides involved in body weight regulation in rats. $\mathrm{J}$. Neuroendocrinol., 19(5): 364-373

27- Abrass CK (2004): Cellular lipid metabolism and the role of lipids in progressive renal disease. Am. J. Nephrol., 24(1): 46-53

28- Bsgby SP (2004): Obesityinitiated metabolic syndrome and the kidney. a recipe for chronic kidney disease. J. Am. Soc. Nephrol., 15(11); 2775-2791

29- Woo MN, Bok SH, Lee MK, Kim HJ, Jeon SM, Do GM, Shin SK, Ha TY and Choi MS (2008). Anti-obesity and hypolipidemic effects of a proprietary herb and fiber combination (S\&S PWH) in rats fed high-fat diets. J. Med. Food 11(1); 169-78

30- Kochikuzhyil BM, Devi K, Fattepur SR.(2010): Effect of saturated fatty acid-rich dietary vegetable oils on lipid profile, antioxidant enzymes and glucose tolerance in diabetic rats. Indian J. Pharmacol., 42(3):142-5.

31- Yu YH and Ginsberg HN (2005): Adipocyte signaling and lipid homeostasis: sequelae of insulin-resistant in adipose tissue. Circul. Res., 96(11): 1042-1052

32- Desprès JP, Ferland $M$, Moorjani S, Nadeau A, Tremblay A, Lupien PJ, Theriault $G$ and Bouchard $C$
(1989): Role of hepatictriglyceride lipase activity in the association between intraabdominal fat and plasma HDL cholesterol in obese women. Arteriosclerosis 9(4): 485-492

33- Davidson MH (2006): Mechanisms for the hypotriglyceridemic effect of marine omega-3 fatty acid. Am. J. Cardiol., 98(4A): 271-331.

34- Barcelli UO, Weiss M, Beach D, Motz A, Thompson B. (1990): High linoleic acid diets ameliorate diabetic nephropathy in rats. Am. J. Kidney Dis., 16(3): 244-251

35- Harris WS and Bulchandani D (2006): Why do omega-3 fatty acids lower serum triglycerides. Curr. Opin. Lipidol., 17(4): 387393

36- Lu Z, Wang Z, Wang $X$, Diao $B$, Feng $X$, He F, Zou $Q$ and Gan L (2009): Protection from high-fat-diet-induced impaired glucose tolerance in female Sprague-Dawley rats. Gyncol Endocrinol. . 25; 464-471.

37- Afonso RA, Lautt WW, Schafer J, Legare DJ, Oliveira AG and Macedo MP (2010). High-fat diet results in postprandial insulin resistance that involves parasympathetic dysfunction. Br. J. Nutr., 104(10): 1450-1459.

38- Amin KA, Kamel HH, Abd Eltawab MA. (2011): Protective effect of Garcinia against renal oxidative stress and biomarkers induced by high fat and sucrose diet. Lipids Health and Disease 10: 6

39- Ceriello A, Motz E.(2004): Is oxidative stress the pathogenic mechanism underlying insulin resistance, diabetes, and cardiovascular disease? The common soil hypothesis revisited. Arterioscler. Thromb. Vasc. Biol., 24(5):816-23. 
40- Storlien LH, Kraegen EW, Chisholm DJ, Ford GL, Bruce DG and Pascoe WS (1987): Fish oil prevents insulin resistance induced by high-fat feeding in rats. Science 237(4817): 885-888

41- Lovejoy JC (2002): The influence of dietary fat on insulin resistance. Curr. Diab. Rep., 2(5): 435-440

42- Mori TA, Woodman RJ, Burke V, Puddey IB, Croft KD and Beilin LJ (2003). Effect of eicosapentaenoic acid and docosahexaenoic acid on oxidative stress and inflammatory markers in treated-hypertensive type 2 diabetic subjects. Free Radic. Biol. Med., 35(7): 772781

43- Cindik N, Baskin E, Agras PI, Kinik ST, Turan $M$ and Saatci U (2005): Effect of obesity on inflammatory markers and renal functions. Acta Paediatr., 94(12); 1732-7

44- Erdei N, Tóth A, Pásztor ET, Papp Z, Edes I, Koller $A$ and Bagi $Z$ (2006). High-fat dietinduced reduction in nitric oxidedependent arteriolar dilation in rats: role of xanthine oxidasederived superoxide anion. Am. J. Physiol. Heart Circ. Physiol., 291(5): H2107-2115.

45- Moncada S and Higgs A (1993): The L-arginine-nitric oxide pathway. N. Engl. J. Med., 329(27):2002-2012.

46- Martins MA, Catta-Preta M, Mandarim-de-Lacerda CA, Águila MB, Brunini TCM and Mendes-Ribeiro AC (2010): High fat diets modulate nitric oxide biosynthesis and antioxidant defence in red blood cells from C57BL/6 mice. Arch. Biochem. Biophys., 499(1-2): 5661
47- Dangardt F, Osika W, Chen Y, Nilsson U, Gan LM, Gronowitz E, Strandvik B, Friberg $P$. (2010): $\omega-3$ fatty acid supplementation improves vascular function and reduces inflammation in obese adolescents .Atherosclerosis 212(2): 580-5

48- Reddy GB, Satyanarayana A, Balakrishna N, Ayyagari R, Padma M, Viswanath $K$, Petrash JM. (2008): Erythrocyte aldose reductase activity and sorbitol levels in diabetic retinopathy. Molecular Vision 14: 593-601

49- Dunlop M (2000): Aldose reductase and the role of the polyol pathway in diabetic nephropathy. Kidney Int. Suppl., 77: S3-12

50- Furukawa S, Fujita T, Shimabukuro M, Iwaki M, Yamada Y, Nakajima Y, Nakayama $O$, Makishima $M$, Matsuda $M$ and Shimomura I (2004): Increased oxidative stress in obesity and its impact on metabolic syndrome. J. Clin. Invest., 114: 1752-1761

51- Olusi SO (2002): Obesity is an independent risk factor for plasma lipid peroxidation and depletion of erythrocyte cytoprotecticve enzymes in humans. Int. J. Obes. Relat. Metab. Disord., 26(9): 11591159

52- Amirkhizi F, Siassi F, Minaie S, Djalali M, Rahimi A, Chamari M (2007): Is obesity associated with increased plasma lipid peroxidation and oxidative stress in women. ARYA Atherosclerosis Journal 2(4): 189-192 


\title{
تأثير زيت الدولفين علي كلي الجرزان التي تتناول وجبة عالية الطاقة غنية بالدهون
}

\author{
نعمة علي سلبيان، ولاء عرفة كشك هيك
}

قسم الكيمياء الحيوية الطبية كلية الطبـ ولاءئ جامعة طنطا

مقدمة البحث : تعد السمنة أحد امر اض التمثيل الغذائى، و التى يكون فيها نسبة النسيج الدهنى فى الجسم أكبرمن

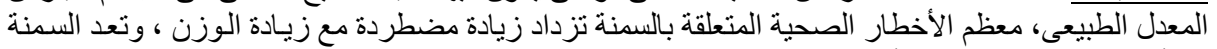

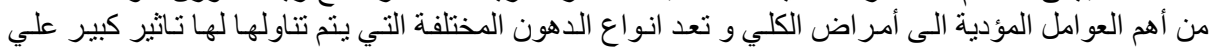

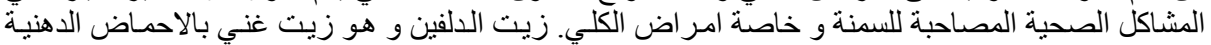

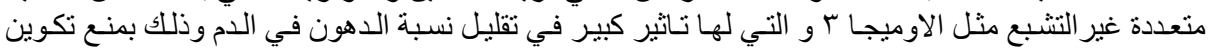

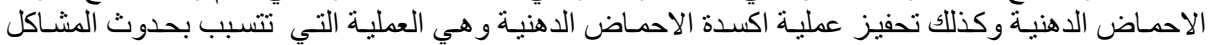

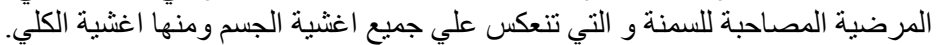

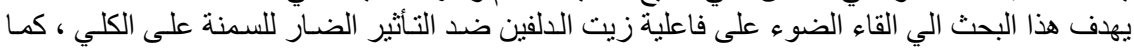

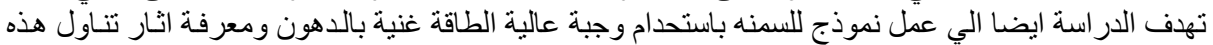

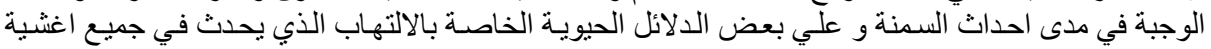

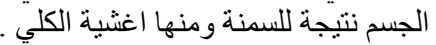

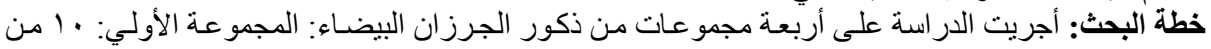

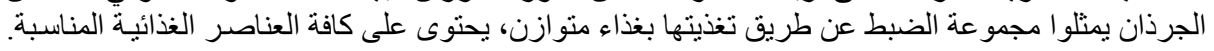

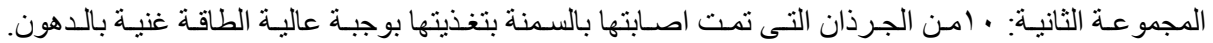

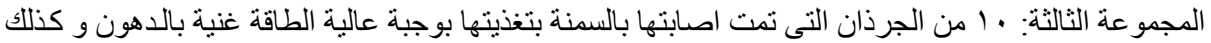

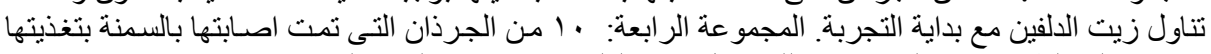

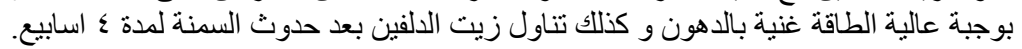

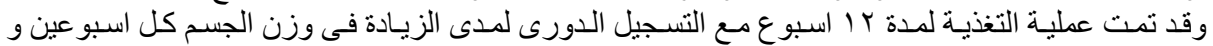

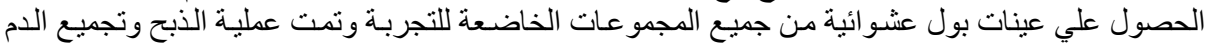

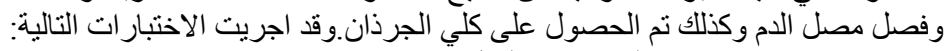

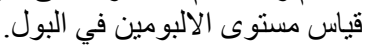

قياس مستوى السكر و هرمون الانسولين الصائم وكذللك مستوي البوليناو لئاو الكرياتينين في مصل الدم.

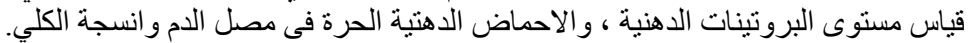

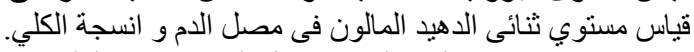

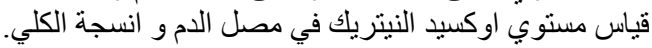
قاس نثاط انزيمختزل الالدوزفي انسجة الكلي. وقد أسفرت الدراسة عن النتائج الأتية:

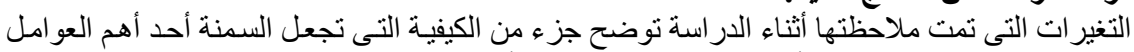

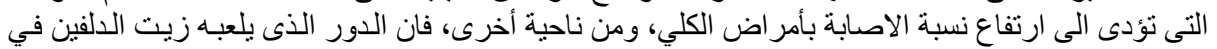

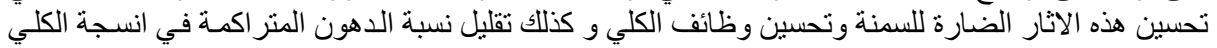

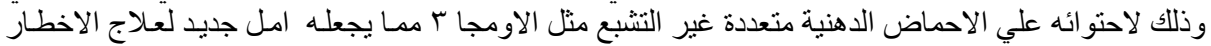

